\title{
RESEARCH PROBLEMS OF THE RELATION OF POWER AND SELF-GOVERNMENT IN THE PROCESS OF POLITICAL MANAGEMENT OF THE COUNTRY
}

\section{Larysa Dunaieva}

\section{INTRODUCTION}

Modern world development is characterized by crisis phenomena in the functioning of all social systems of the world, which have spread in the world in recent decades, have led to significant consequences in the economic and social space and are increasingly manifested in the sphere of politics. Almost all political institutions and processes, especially the modern states, political parties and other actors of world and national politics, have felt destructive consequences. The political system of countries is in crisis. The models of power and governance that have previously provided for effective governance of the country are changing and proving their inability to meet the new conditions and needs of the times.

The system of governing countries, which is predominantly the sphere of government, is less and less able to respond adequately to the new needs of social development, to influence all social processes, and does not absorb all policy makers. Due to the fact that the state administration does not cover the system of self-government and the sphere of civil society, political scientists argue that it is advisable to change the priorities in the management of modern countries - from state to political administration, capable of covering everything that has to do with politics.

Social practices require urgent changes in the system of government and political governance that can meet the challenges of globalization, the spread of crisis in the world socio-economic space, the emergence of new actors in the political arena, while reflecting historical, national, cultural, ethnic and other features of every country, every society. All this requires the transformation of the political governance model of the modern country, taking into account new opportunities of the authorities and self-governing processes, their rational correlation in the process of political management in practice.

The search for a new model of political governance is also complicated by problems in the social sciences, due to the lack of an adequate paradigm of thinking and a methodological basis for research and analysis of new phenomena in world and national politics. 
Today, political science faces the urgent problem of reviewing the balance of power and self-government in the process of political governance of the country, developing a model of relations between them that would fit the culture of the society, the requirements of time, and forming adequate to the real needs of interactions of power and self-government in the system of political management on the basis of such a model. All this requires the development of theoretical and methodological foundations for determining the place and role of government and self-government in the process of political management of modern societies.

\section{Theoretical and methodological aspects of the study of the relationship between power and self-government}

Modern world development is characterized by the growth of pluralism and the presence of numerous competing paradigms of social development, among which the sociohumanist paradigm occupies a leading position. It emphasizes the change of the place of the person in the social structure of modern society, the growth of the range of his freedom and individuality, overcoming alienation, etc.

The analysis of such paradigms proves that the theory of complex nonequilibrium systems, developed by I. Prigozhin, is today the scientific and methodological basis of most scientific studies, including political ones ${ }^{1}$. It is a fundamental denial of the predictability of the future as a product of selfdevelopment, which cannot be a pre-planned process. One can only hypothesize development trajectories based on quantitative data. However, the normative function of the social sciences is not to construct a future reality, but to find out how it is formed, and at the same time, to promote a more rational reality by comparing social constructs. It is important to understand that such justifications will always be not only relative but also of exclusive use in well-defined systems.

Modernity is characterized by three features: the spread of information technology, globalization and the emergence of networked organizational forms in all spheres of human life. Globalization is the main process that has a dominant influence on the configuration of relations between government and self-government in the process of political governance of modern states.

Globalization refers to the process of global economic, political and cultural integration, the main characteristics of which are: world division of labor, migration across the globe of human, industrial and financial resources, as well as standardization of legislation, convergence of cultures of different S. 23.

${ }^{1}$ Prigozhin I. Vremya. Khaos. Kvant / Y. Pryhozhyn, Y. Stynhers. - M.: Nauka. 1998. - 
countries. In politics, this is manifested as a certain reduction of the role of state power and the shift of emphasis to global international organizations at the macro level, and at the local level - the localization of power at the level of a city-state governed by self-government mechanisms.

Mass spread of information technology and the spread of globalization processes are gradually leading to the formation of appropriate organizational forms - networks, first in the sphere of economy, then in society, and as a consequence, in the political sphere. The first to undergo some changes due to the penetration of network forms into the sphere of political governance is the institution of local self-government, since it is closest to the citizens of the level of government, and by its nature the network is formed on the basis of trust and desire to achieve a common goal.

In this regard, when developing its own model of the political system, Ukraine must take into account the impact of the effects of globalization processes, above all, on economic and political ones. In the new model of the political system, it is important to focus on self-governing aspects, as they lead to the formation of relationships of trust between network members, on the basis of which it is only possible to build a new model of power relations in the post-Soviet political space that will correspond to the realities of the times. "So, in the face of modern Ukraine, there is an urgent problem of finding an appropriate model of government, which is able to satisfy all the requirements of Ukrainian society. It is necessary to devise a form of government that is capable of providing economic growth and strengthening of political formation and, at the same time, contributing to social stability in a society where not many members of the new class coexist, and numerous representatives of the old age, who are largely unadapted to their realities days, and therefore require social assistance from the authorities"2.

The development of a new model of the political system of modern society requires study of both the world and national historical experience of becoming a system of public power organization, government and selfgovernment, and their ideological and theoretical, intellectual understanding.

\section{Ideological and theoretical origins of the organization of modern public power}

Analysis of the political and legal heritage of the most prominent thinkers from antiquity to the present gives reason to claim that the first ideas about the relations of "authority-autonomy" were held within the doctrine of the ideal (perfect or correct) form of government. According to the ancient Greek

2 Dunayeva L. M. Vlada i samovriaduvannia: evoliutsiia dialohu [Monohrafiia] / L. M. Dunaieva / Odesk. nats. un-t, - Odesa: Polihraf, 2009. - S. 65-66. 
thinkers, the ideal form of government can only be a mixed form of statehood, provided that the policy in which the features of the civilian community are preserved is maintained. The political and legal formation of Ancient Rome was something else: the Roman state underwent a long evolution from tsarist power, republican form of government, and to imperial power. Moreover, if in the first stages of the statehood of Rome the essential features of the civilian community were preserved, then during the periods of principle and dominance a vertical of power was formed with a centralized bureaucratic apparatus that controlled the local government.

Political and legal thinking of the Middle Ages on the consideration of options for the interaction of power and self-government is also diverse. In this period, it is expedient to carry out a study of the interaction between the authorities and the structures of self-government, by means of a comparative analysis of the medieval Byzantine (Oriental-Orthodox) tradition and the principles of the Occidental-Catholic tradition, on which both state practice and political-legal theory of Western states relied. A key factor in analyzing both political and legal traditions is that both the incidental and the orientational directions are based on the ancient heritage and the Roman law school. But as a result of changing historical and religious-cultural conditions, completely different state-legal systems were formed, and in particular different approaches to understanding the optimal relationship between central government and self-governing structures in national political systems. In general, at this time, we can distinguish the following main areas:

- Byzantine (Eastern Orthodox) tradition, which saw the monarch as the supreme sovereign, who should combine secular, ecclesiastical and selfgoverning power in his own hands;

- the theological (Catholic) tradition according to which the monarch must submit to religious power in order to legitimize secular power (both central and self-governing);

- the secular tradition of civic humanism, according to which the people are the only sovereign power, but delegate it to a legitimate monarch.

Analyzing the political and legal heritage of the Middle Ages and the Renaissance, it should be borne in mind that the concepts of most scholars of this period were based on ancient heritage, representing a kind of synthesis in the Aristotelian tradition of Italian humanism, the idea of the state, which is based on the achievement of common good and values of self-government structures. For humanists, it is common belief that the goal of the state should be to ensure the happy life of its citizens, and for the sake of this the state should not restrict civic initiatives. Thus, the Italian humanists defended the ideas of socio-political ethics.

The most interesting to clarify the question of political and legal interpretations of the interaction of power and self-governing structures during 
the Middle Ages and the Renaissance is the study of N. Machiavelli's theoretical heritage. The ideal of statehood for Machiavelli is a mixed government in the form of a moderate republic, which is recognized as the most stable in its political development, because it combines several forms of government, as well as different forms of self-government.

Approaches to the understanding of power and self-government of the period (XVIII - XIX centuries) focus attention on the innovations of political life and socio-political thought of modern times, in particular, the establishment of the institution of local self-government and the emergence of ideological and political currents, which led to a rethinking of the relations between the authorities and the sciences in the political practice of the time.

Currently, the basic scientific concepts of local self-government have been formulated, in particular, state, public, natural and legal. Despite the fact that the subjects of their research were completely different politically; from the state, they, each in their own way, came to the conclusion that the true greatness of the peoples was based on a system opposite to centralism. Selfgovernment was defined as an organically inherent social regulator of cohabitation at the local level and a state-legal institute capable of decisively influencing the degree of democratic political systems.

Modern times were characterized by the formation of ideological and political trends, which also influenced the evolution of ideas about the model of relations "authority-autonomy ". Thus, the set of liberal ideas and postulates greatly influenced the idea of power and self-government, which played a revolutionary role in the transition of European countries from feudalism to capitalism. It was thanks to the liberal trend in the late nineteenth century. Most state and public figures were convinced that the basis of a constitutional system of a democratic state should be recognition of human rights, broad self-government, and the relationship between central and local authorities should be based on an equal footing.

The ideal of social order for representatives of other ideological and political currents - anarchists and anarcho-syndicalists - was federalism, full autonomy, independence of local self-government bodies from the center, self-organization of society, voluntary association of production associations, which should be responsible for the organization of production and distribution. The links of the future society proclaimed revolutionary labor unions (unions of industrial and public self-government). On the example of anarchist and anarcho-syndicalist theories, we see that despite all political, social and economic transformations, the overriding value is that people living in one place and in need of certain services should have democratic institutions through which they had would be able to express their interests. 
The initial theoretical and methodological basis for the formation of public, including self-government, in Ukraine is the public and natural-legal concept of power and self-government. These ideas humanize public authority, make it more citizen-friendly, and their implementation substantially broadens the sphere of individual freedom, its social action, forming an essential segment of its social interaction with the state, which optimally realizes individual and collective rights of the individual. Authorities under these conditions reflect not only the specific way of thinking and the form of realization of the will of a particular person, groups of people for the life and life of their descendant. At the local level, such a power will form and operate a coherent system of social connections that actually shape a real civil society.

For the political thought of the XX century the nature and principles of functioning of power and local self-government is characterized by the evolution of scientific ideas about the model of the relationship between "power and self-government". In this time interval, it is advisable to distinguish three stages. Thus, the beginning of the century was marked by the development of the problem within the idea of the rule of law, the Soviet times introduced their vision of these relations, and modernity added its scientific principles and models of relations in accordance with the requirements of modern democracies.

The beginning of the twentieth century proved that the problems of the essence and content of power and self-government are embedded in the content of the phenomenon of self-restriction of state power and movement to the rule of law, as the state that guarantees the most natural rights for the individual. However, with respect to domestic political practice, it should be noted that the bourgeois-class self-rule of capitalist countries has acquired in the USSR the form and content of proletarian-class self-government. This fundamentally changed the notion that existed before the revolution about local government as a non-state by nature.

According to the Soviet approach, the local Soviets freely united on the basis of democratic centralism into a single, federal, consolidated, nationwide Soviet power. Organized into a rigid state vertical, local councils were, in fact, a democratic cover for the party's monopoly power. From the fact that the councils tried to provide traditional municipal services to people with their limited capabilities, their nature did not change. They formed and acted as an organic part of the totalitarian regime. In part, this approach remains in the ideas of the modern population of Ukraine, which is manifested in the fact that people still consider self-government as an extension of state power rather than an independent kind of government.

Already in 60-80-ies of XX century the scientific and educational literature analyzed the problems of self-government of the people in 
connection with the democratic processes that took place in the state and public life of the country, with the activity of councils and the strengthening of democratic principles in government. However, self-government was not limited to the local level, but was considered as a social phenomenon that penetrates into all spheres of life of society and its political system. It was not limited to advice; its forms, such as self-government of public organizations, labor collectives, cooperative, school, student self-government, were actively investigated, which in their totality formed the concept of "self-government of the people".

\section{Modern theoretical and methodological approaches of researching the balance of power and self-government}

Local self-government in the conceptions of modern political concepts is a new "publicity", which, compared to the state, has a different nature of relations between subjects and objects of governance. In comparison to the state, local self-government acts as an equal subject of government, which has autonomy within its powers. Only, unlike the state, local self-government assumes that the entities are the links of the system of their own, not of the state government.

Various terms are used to define political governance within modern science, including management and governance, but the latter is a more inclusive phenomenon that involves not only governmental structures but also informal and non-governmental mechanisms.

There are several concepts of political governance, among which the most common are the concepts of governance as a socio-cybernetic system and governance as self-regulatory inter-organizational networks. In this approach, governance is the result of socio-political-administrative intervention and interaction, and the existing order in the political sphere is not dictated from above but emerges in the process of negotiations between representatives of different structures. These interactions are based on recognition of interdependence; they do not have a single actor, public or private, who has all the knowledge and information needed to solve a complex of existing problems. This approach clearly delineates the difference between public and political governance, recognizing the latter as broader in that it encompasses public administration and civil society, the private sector, and others.

The current concept of political governance as self-regulating interorganizational networks is changing the place and role of government as a leading actor of state power. The government is no longer the basic structure of political governance. The political system is highly differentiated. The objectives of the government are to provide opportunities for socio-political 
interaction, to stimulate multiple and diverse mechanisms for solving problems and for the distribution of services between several actors.

Each country is developing its own version of political governance, but theoretically one can imagine a universal model that would capture all the benefits of the best political management experience. "Governance is a function of content in interaction with form. Therefore, the higher and more adequate the content at the 'input' and 'output' of social integrity, the higher and more adequate the management, and therefore the higher and more qualitative is the form of such integrity" .

In modern political science there is a significant shift in the study and interpretation of the category "power". There is a transition to the next, qualitatively new level - the very way of reproducing the schematism of power. This means that certain options of power become technically constructed. Indestructible things turn into relative ones. Power technologies are evolving, and we are increasingly beginning to relate to power from a technical point of view as we can discuss what type of power is to be established and how.

To realize all the schematism of modern power, it is necessary to recreate its entire integrity. The schematism of power in this sense is realized as a definite, defined configuration, which provides a certain way of interconnecting the transcendencies of power, authorities, elites, places of presence and people. If any of the components is missed, it can lead to negative consequences.

The state is only one of the instances of the authorities, which possesses a rather defined exclusive resource (general procedure and uniformity of procedures throughout the territory) and one which does not substitute for other instances. Historically, L. Montesquieu was the first to record the principle of several irresistible authorities. It is not about the separation of powers - it is not about how one power was divided into three parts, but rather that there are several separate instances of power, each of which has exclusive resources, and these instances have to agree among themselves.

The possibility of multiple instances of power in parallel has given rise to several separate types of power, including political, public, state, local selfgovernment and so on. They are all different in purpose, methods, forms of manifestation, objects and subjects. And the change in power configuration is due to three processes: the integration of trust networks, the isolation of categorical inequality, and the elimination of independent centers of power that resort to violence and coercion.

\footnotetext{
${ }^{3}$ Hrazhdan V. D. Deiatelnost y upravlenye (sotsyolohycheskyi aspekt) / V. D. Hrazhdan. M.: NYY truda, 1989. - S. 36.
} 
The needs of democratic governance require a combination of political governance in the country and state power and local self-government. In most democracies, the regional level of government is the most important, and its management is represented by local self-government and state authorities, which should cooperate at this level on the principles of interdependence and the combination of their own efforts.

In analyzing the regional structure of a society, the general criteria - the characteristics of the subject and the object of power, are taken into account. Subject research involves identifying a source of regional authority that can co-ordinate with central government and be governed by direct government; or act as a regional self-organization of power in the form of full selfgovernment. The object of regional power is characterized by a regional socio-political community, the distinctive features of which are the particular political organization and the presence of integrating political interest.

In the presence of a territorial socio-political community in the region, the laws of its development become a determining factor in the political organization of the region, and all actions are aimed at reducing the powers of the central state power, forming the structures of self-government and selforganization of power. In the absence of such a community in the region, the central source of government and its interests will be the main source of development of its forms. The central government will try to establish its own control in the region. A capable political actor is formed where and when there are not only central government bodies at the regional level, but also a society with all the relevant attributes and characteristics.

Significant reasons for increasing the importance of regional and local levels of government as centers of public decision-making in globalized conditions are the sharp increase in the economic impact of urban areas and the diminishing role of the state. Today, we can talk about different areas of analysis of the place of regions and regional policy in a globalized world, but only the model of "global gates" allows to include and explain the place and role of transitional economies and developing countries in the global globalization process.

Such "gates to the global world" are built on negotiation practices, trade networks and trust, and can exist as shared centers of economic, political, and intellectual networks, and at a distance, distance from one another. "Gates" can be different: "global gates", which are centers of transit trade and credit for the whole "world-economy" and "quasi-turn", which are the center of the "world-empire" - the world, built on the administrative and political domination of networks power. As a result of the quasi-turn, only politically controlled countries attract resources. The former are based on a broad democratic basis, in particular involving self-organization and self-governmental 
processes within networks, and the latter requiring a strong political and administrative influence over the controlled territory, which implies the strengthening of power and the partial curtailment of self-government and self-organizational processes.

The analysis of modern political systems needs to be considered in terms of the principles of the distribution of power vertically, namely between the central government and the regions, their local structures, which is especially important for understanding the problems of interaction between the authorities and local self-government.

Under unitarianism, the separation of powers between the various instances of government in the state is carried out by the central authority local self-government bodies, and the principle of separation of powers should be supplemented by a system of checks and balances, which under conditions of unitarism works for the benefit of the central government. Federalism gives a different configuration of power in the state, since it adds hierarchy to the very structure of power that is enriched in the federations by an additional level of concentration of power - the subjects of the federation. The peculiarity of federal power-building is the shift of power accents to the middle level - the level of subjects of the federation where the efforts of the central authorities, as well as self-government of different levels, must be coordinated and harmonized.

From the second half of XX century the concept of a "new federalism" is gaining ground in the global political field, which places greater emphasis on the autonomy of territorial self-governing units, taking into account the interests of ethnic and national minorities, the role and function of regional elites. This approach adds even more hierarchy to the system of government, since it also has primary centers of self-government (neighborhoods), which, on the one hand, complicates the system of government, and on the other, promotes the unification of political governance systems in all modern states, a federation is a unitary state.

It is possible to combine the gains of both federalism and unitarism within the limits of a new scientific-theoretical and practical approach - regionalism. This is where his supporters come from. They consider the region to be a link to governing the state, which is recognized by both federalism and unitary states, and globalization challenges call for local problems in an urgent and unified scenario, making regionalism an increasingly widespread scientific area of research and practical policy action.

Such a theoretical and methodological basis for the organization of power and its interaction with local self-government can be served by many principles proposed by the world government, in particular, systemic, hierarchical, democracy, etc., however, the ones that are recognized by the 
world as the most effective are the principle of decentralization, subsidiarity and control. In their content, they are a significant complement to the principle of separation of powers, detailing and prescribing those theoretical and methodological foundations on the basis of which the process of political governance in the modern state should take place.

The principle of decentralization is a complex phenomenon, since it is necessary to clearly understand the difference between decentralization of power and decentralization of government on the one hand, and between decentralization and deconcentration on the other. The decentralization process involves the transfer of the right to make decisions independently to the lower levels of government, but there is a prerequisite - these lower levels of government must be governed by elected councils, that is, self-government. The process of devolution of power implies the transfer of powers to perform only within one branch of power - the executive, and therefore can only be considered within the limits of public administration.

One example of a rational decentralized government is the experience of France, the main characteristics of which, according to B. Gourne, are that:

- the region is transformed into a territorial community, which, as communes and departments, is governed by freely elected councils;

- Heads of Assembly of Territorial Communities were given more power;

- the state guardianship has been abolished, but the state continues to exercise administrative control over certain actions of territorial communities, as well as control over certain budgetary operations;

- decentralized communities have benefited significantly from the expansion of their mandate;

- the state's financial support has become global ${ }^{4}$.

Another important principle of political governance is the principle of subsidiarity, which has long-standing historical roots and rich experience in the application of political practices in European countries. According to this principle, at the lower level of government, such powers should be concentrated that the community is able to fulfill on its own, but subject to material and financial assistance from above. Only functions that the community is unable to master are passed to the highest level. Each country, in each specific historical period and taking into account all historical, cultural and national-mental levers, determines independently the amount of powers that the self-governing community is able to fulfill on its own and at its own discretion.

${ }^{4}$ Hurne B. Derzhavne upravlinnia [per. z frants.V. Shovkuna]. - K.: Osnovy, 1993. S. 14-31. 
When applying the principles of decentralization of political governance and subsidiarity, it should be remembered that only powers are delegated to the lower level and vice versa, and the responsibility rests with whom it naturally belonged. In addition, one should not forget that no matter how you act or delegate authority, the power remains united.

Delegation and distribution of powers between different levels of government, especially given the inability to delegate responsibility, requires the application of the principle of control. For now, such control has two directions. One is the control of the authorities, and in particular the supervisory bodies specially created for this purpose, and the other is the public control. The latter is favored, as voter control is an effective form of control in leading democratic countries, and control of independent civil society organizations is gaining momentum.

Modern Ukraine is in a state of search for an optimal model of the relationship between state power and local self-government. In this direction, the political system of modern Ukraine is being reformed, with the aim of establishing a new model of government: a person - a community - a state that is responsible for the democratic rule and realities of modern sociopolitical and economic life imbued with globalization processes and all its consequences: poverty, social intensity, localization, etc.

For the implementation of such a model of the political system, a number of reforms have to take place, which can be structured as follows: constitutional reform - administrative-territorial - land - budgetary and tax governance reform - reform of local self-government. It is the preservation of such consistency that will allow building the basis of the whole model of political governance - a strong and effective community, capable of meeting the needs of every citizen of Ukraine, bringing the whole system of government closer to the human level.

The reform of the principle of decentralization of power, with an emphasis on its action not only at the level of the local community but also at the level of regional self-government, needs to be improved during reforms. Regional self-government should truly become an institution of self-government, not of government. For this purpose it is advisable to introduce executive committees of regional councils and give them considerable competence in managing the territory of the region. This will implement the principle of decentralization not only of government but also of power, which is a requirement of a democratic state of the modern European model.

The next step is to improve the implementation of the subsidiarity principle in our country, which should be supported by an appropriate material and financial basis. This can be achieved through land and fiscal 
reforms aimed at strengthening territorial communities and their interest in the economic development of the territory.

Further reform of the system of government in Ukraine depends on society, on its activity in discussing the concepts of reform and encouraging existing politicians to take appropriate action through public organizations, political parties, etc.

\section{CONCLUSIONS}

The analysis of the theoretical and methodological foundations of public power, the correlation and interaction of power and local self-government in foreign and Ukrainian special literature indicates an active search for an adequate theoretical basis for transforming existing models of political systems to meet the needs of contemporary historical challenges. This is especially true of the crisis-stricken Ukrainian society, which is seeking a model of government and government that can provide political stability in society and in power, find a way out of a lasting political and economic crisis, foster confidence-building in society, etc. This requires reforms that are appropriate to begin with administrative-territorial, then reforms of local selfgovernment, which aim to form in Ukraine a strong institution of local selfgovernment, strengthen the regional level of government and strengthen the local community as a socio-political community aspiring to self-government. Political reform should be conclusive, where all the gains of previous reforms will be concentrated and brought into line with central government institutions.

The new model of political governance, to be developed in accordance with the conditions of modern Ukraine, should have three levels: center region - community. The balance of power and self-government in such a model will be equilibrium, since the three links will coordinate power in the way of authority. Thus, the highest concentration of power should be concentrated at the center level, as all the main institutes of state power and administration - the Parliament, the President, the Cabinet of Ministers, committees and departments - are represented in the capital.

The leading link in such a model of governance should be the region, at the level of which must be balanced both by the government and the selfgovernment. Only such an equilibrium way of balancing power and selfgovernment and regional levels will allow it to develop steadily. This approach to the consideration of regional governance will strengthen the whole system of political governance of the society and will allow the regional centers - big cities-metropolises to claim the status of regional gates in the global world, to ensure the development of the whole society. 


\section{SUMMARY}

The article deals with theoretical and methodological, ideological and theoretical origins of public authority and local self-government in their genesis, interaction and correlation. These issues are considered on the basis of modern conceptual approaches of forming a new model of the system of governance and self-government in Ukrainian society.

\section{REFERENCES}

1. Dunayeva L.M. Vlada i samovriaduvannia: evoliutsiia dialohu [Monohrafiia]. Odesk.nats.un-t. Odesa: Polihraf, 2009. 356 s.

2. Hrazhdan V.D. Deiatelnost y upravlenye (sotsyolohycheskyi aspekt). M.: NYY truda, 1989. $150 \mathrm{~s}$.

3. Hurne B. Derzhavne upravlinnia [per. z frants.V. Shovkuna]. K.: Osnovy, 1993. $257 \mathrm{~s}$.

4. Pryhozhyn Y. Vremia. Khaos. Kvant. M.: Nauka. 1998. 438 s.

Information about the author:

Larysa Dunaieva,

Doctor of Political Science, Professor

Odesa National I. I. Mechnikov University 15/13, Tenistaya str., Odesa, 65009, Ukraine 